\title{
INDSTILLET PÅ ET MIRAKEL
}

\author{
Karismatisk bøn på Færøerne
}

\section{JAN JENSEN}

Midt i januar 2020 går jeg op ad de stejle betontrapper, som fører op til et lille kontor, som tilhører City Church, og som bliver brugt af kirkens pastorer og andre medhjælpere. Jeg banker på døren til kontoret, og Hanna, kirkens kvindelige pastor, åbner med et stort smil. Dette er nu tredje omgang, at jeg laver feltarbejde i kirken, og på dette tidspunkt er kirken igen i gang med at genoverveje, hvordan den bedste måde at gøre tingene på ser ud. Vi snakker sammen om løst og fast i omkring en times tid, inden Hanna begynder at snakke om sin egen måde at „være sammen med Herren“ på i sit daglige liv. Bibellæsningen er en stor del, ligesom den har været, siden Hanna kom til personlig tro på Jesus som barn, men hovedparten af den daglige relation med Gud, siger hun, er i bøn. For mig er dette ingen overraskelse. Igennem de mange måneder, som jeg har tilbragt sammen med kirkens medlemmer, er bøn ofte blevet fremhævet som en central del af det gode kristne liv, og jeg har selv oplevet at stå midt i bønnecirkler før og efter gudstjenester og er blevet personligt bedt for flere gange, både på tomandshånd og i større sammenhænge. Som samtalen udvikler sig, kommer Hanna mere ind $i$ dybden af, hvad bøn indebærer, og tilbyder her en overraskende indsigt $i$, hvad bøn indebærer for hende. Hun siger, at hun engang havde hørt et udsagn, som har fulgt hende: „Hvis du kun har mulighed for at bede i ti minutter, så brug som minimum syv af de minutter bare i tilbedelse - giv Gud tak for, hvor god Han er, og reflekter over Guds nærvær.“ Bøn er her grundet i en tilstand, hvor Hanna selv tilsidesætter sine egne behov og tanker for hellere bare at „være til i Guds nærvær“. Det er denne tilstand, jeg kommer til at forfølge igennem denne artikel, samtidig med at jeg forsøger at vise, hvad det indebærer at ,give Gud tak", og hvorfor dette overhovedet er en nødvendighed. Jeg argumenterer for, at dette skal forstås som en subjunctive $e^{1}$ indstilling til verden og gør en åben for at blive virket på af Gud som en udefrakommende aktør. 


\section{Det velsignede liv}

Den subjunctive tilstand, som jeg her omtaler, er baseret på indsigter, som jeg har skabt mig, siden jeg først begyndte at lave etnografisk feltarbejde på Færøerne i 2016. Dette feltarbejde består af tilsammen et års tilstedeværelse på Færøerne udover omkring tre måneders feltarbejde over nettet, hovedsageligt med medlemmer af City Church. I disse måneder har jeg lavet deltagerobservation $\mathrm{i}$ kirken både som gæst og som aktivt medlem af kirkens tekniske personale udover at lave interviews med kirkens medlemmer. Jeg lægger ud med en beskrivelse af, hvordan den subjunctive tilstand skal forstås i denne sammenhæng.

Sharon er en amerikansk kvinde sidst i 40'erne, som er gift med en færing, og som har boet fast på Færøerne siden 2010. Sharon mødte sin mand, mens de begge var tilknyttet Livets Ord i Uppsala, Sverige, midt i 1990'erne (jf. Coleman 2000). Sharon fortæller, at da hun først flyttede til Sverige som 23 -årig, var dette en stor ændring fra hendes kendte liv i Pennsylvania, men efter at flere af hendes søskende allerede havde valgt at tage samme rejse, valgte hun også at springe ud i det. Hun beretter, at denne tid fuldstændig ændrede hendes forhold til Gud. Sharon fortæller:

Jeg var vokset op med, at meget af mit forhold til Gud gik igennem mine forældre. Min far var pastor i en kirke, så for mig var det almindeligt, at jeg blev bedt for igennem ham, og at jeg på den måde var tæt på Gud. Men da jeg tog til Uppsala, ændrede det sig fuldstændigt. Jeg stod pludselig på egne ben, og tiden i Livets Ord var fantastisk. Det var Gud, som bevægede ting der. Så mange mennesker, så meget tilbedelse, og man kunne virkelig mærke Guds nærvær. Det var her, at jeg virkelig begyndte at bruge tid sammen med Gud. Hver dag brugte jeg flere timer på at læse i Bibelen, men mest af alt at bare med være i Guds nærvær. I bøn og igennem musik og sang. Og lige pludselig begyndte ting at ske. Ting, som ikke burde ske. I den usikre økonomiske situation, jeg stod i som ung amerikaner langt hjemmefra, begyndte tingene bare at gå op. Jeg fik uventede jobs ved siden af bibelskolen og fik doneret studierejse til Israel. Man tænker ofte 'kan det virkelig passe?', ligesom alle normale mennesker ville tænke. Men det var der, jeg oplevede Ham som virkelig virkelig. Kun mig og Ham, langt hjemmefra, ingen familie at støtte sig op ad. Der blev mit forhold til Gud personligt.

I dag går Sharon og hendes mand flere dage om ugen i City Church, som ligger midt i Tórshavn, Færøernes hovedstad med omkring 20.000 indbyggere (ud af et sammenlagt indbyggertal på omkring 52.000, ${ }^{2}$ og hver søndag morgen klokken 11 er kirkens hovedsal fyldt med 150-200 mennesker. I modsætning til mange af de andre kirker i landet er City Church demografisk relativt udspredt, og kirken tiltrækker folk fra alle livets omstændigheder - familier med børn, ældre mennesker, unge og teenagere og ikke mindst flere udlændinge, som bliver tiltrukket af kirkens internationale udstråling (med fx direkte engelsk oversættelse under 
gudstjenester og engelsksprogede musiknumre). En af kirkens vigtigste arbejdssætninger er, at de skal møde mennesker der, hvor de selv er, i stedet for at personer, som kommer til kirken, skal leve op til et vist ideal for at kunne passe ind. Af samme grund har kirken valgt at arbejde på, at selve bygningen - med hypermoderne udseende og den nyeste digitale teknologi med imponerende lydog lysudstyr - skal kunne tiltrække folk udefra, som ellers hellere ville tage til en koncert, teaterforestilling eller lignende. I gaderne ser man også flere andre kirker - blandt andet Ebenezer, som udspringer fra den engelskinspirerede Plymouthbrødre-bevægelse (almindeligvis bare kaldt Brødrene), samt Frelsens Hær, som ligger på den anden side af vejen lige over for City Church.

Gåturen igennem Tórshavns centrum denne søndag morgen er stille. Alle butikker er lukkede, og rundtomkring på gaderne ses tomme cigaretpakker og ølflasker, som bevidner den foregående aftens fest og ballade, hvor barer og diskoteker holder åbent til sent ude på natten. Men midt i stilheden finder man også folk, som kører ind til byen i deres biler, eller andre, som kommer spadserende ned mod centrum fra et af de højereliggende beboelsesområder. Søndagens stilhed kan dog være misvisende. Færøernes befolkning er generelt dybt religiøst engageret, og søndag er den ugedag, hvor omkring 24 procent af den færøske befolkning går i kirke ${ }^{3} \mathrm{i}$ en af de 60 aktive lutherske folkekirker eller i en af de omkring 100 såkaldte frikirker (Hansen 2014). Omkring 80 procent af befolkningen tilhører folkekirken, og der er også et livligt frikirkemiljø med de tidligere nævnte Plymouth-brødre som den største gruppe. Blandt disse frikirker finder vi også et stort antal Indre Mission-menigheder og forskellige pinse- og karismatiske kirker. Historisk set udspringer frikirkerne fra de vækkelsesbevægelser, som kom til landet sidst i 1800-tallet, og som stillede sig meget kritisk over for folkekirkens daværende praksis og lære, og det er i denne periode, at kristent liv på Færøerne begynder at tage den form, som det har i dag - med mange troende med et meget højt religiøst engagement (Hansen 1984; Jóansson 2012).

Hvor de oprindelige vækkelsesbevægelser (hovedsageligt Brødrene og Indre Mission) så folkekirken som deres modpart, er der igennem det 20. århundrede opstået andre frikirker, som til dels har været del af den samme troskamp, men som også har distanceret sig fra de oprindelige vækkelsesbevægelser. Mest nævneværdigt i denne sammenhæng, og som er mest relevant for foreliggende artikel, er pinsebevægelsen. Relativt kort efter denne bevægelses begyndelse i 1906 ved den såkaldte Azusa Street Revival i Los Angeles, California, ankommer den til Færøerne i sidste halvdel af 1920'erne, hvor svenske missionærer med et tæt forhold til Brødrene begynder at fortælle om nådegaver og om begrebet ,nådens dåb“. Denne lære bliver hurtigt et omstridt emne blandt Brødrene og leder til, at nogle af menighedens medlemmer bryder ud og starter den første pin- 
semenighed, som først for alvor får fodfæste sidst i 1940'erne. Sammenlagt med den karismatiske vækkelse, som har været et globalt fænomen i 1960'erne og 70'erne (jf. Csordas 1994), findes der i dag omkring 2.000 personer på Færøerne, som er tilknyttet bevægelsen.

Disse kirker er kendte for det meget karakteristiske bøns- og tilbedelsesliv, og sammenlignet med andre grupper i landet er den karismatiske tilbedelsesform meget mere kropsligt engageret, og det velkendte billede med den kristne tilbeder med hænderne vendt mod himlen og med lukkede øjne står i stærk kontrast til fx Brødrene og folkekirken. Selve udtrykket er også meget distinkt, hvor den tilbedende ofte høres tale i tunger, danse rundt om sig selv eller i sjældnere tilfælde ligge på gulvet i en slags trance, hvor den Hellige Ånd kommer over personen $\mathrm{i}$ så kraftfuld form, at personen mister fodfæstet. Centralt for denne tilbedelsesform er en stærk tro på, at Gud (oftest forstået som den Hellige Ånd) er meget konkret til stede, og tilbedelsen er således et samspil med denne, hvor handlingskraften går begge veje - både fra den troende hen imod Gud og fra Gud hen imod den troende. Det skal også understreges, at selv om der er langt større kirkesamfund i landet, er det pinse- og karismatiske kirker, som har tendens til at være meget langt fremme i forhold til innovationer inden for religiøs praksis såsom brug af nye teknologier. Den generelt „løse“ tilgang, som disse kirker har til kirkelige rammer, står i stærk kontrast til de andre kirker i landet, og under mit ophold blandt medlemmer af de større kirker bliver det ofte påpeget, at de selv henter inspiration fra disse mindre kirkers ideer og nye praksisser.

Den teologi, som ligger bag dette udtryk, står i stærk kontrast til andre kristne teologier på Færøerne, specielt sammenstillet med den, man ser hos Brødrene. ${ }^{4}$ Brødrene er globalt set,en relativt beskeden bevægelse. Men den teologi, som Brødrene oprindeligt promoverede igennem 1800-tallet, er blevet en bestanddel af en stor del senere kristne bevægelser. Specielt er det læren om dispensationalisme, som den blev fremsat af en af bevægelsens grundlæggere, John Nelson Darby (1800-1882), som går igen rundtomkring i verden. I store træk handler dispensationalisme om, hvordan Gud har forholdt sig til verden (og mennesker) på forskellig vis igennem historien. I forskellige perioder har Gud indgået i forskellige pagter med menneskeheden, som har ligget til grund for den måde, hvorpå menneskeheden kan forsøge og håbe at opnå en tilfredsstillende relation til Gud (jf. Haynes 2020; Jóansson 2012; Robbins 2001; Webster 2013). Et eksempel på dette er, at Gud tilbød Adam og Eva i Edens Have en bestemt måde at bibeholde relationen på, at Moses og det jødiske folk fik Loven, og at menneskeheden gennem Jesu død og opstandelse kan etablere en relation til Gud gennem tro alene. Det centrale problem i vores tilfælde er spørgsmålet om, hvilken dispensation menneskeheden befinder sig i, efter at Det Nye Testamente er blevet til. 
I den færøske kontekst er dette spørgsmål et centralt problem i relationerne mellem forskellige former for kristendom, specielt imellem Brødrene og pinse- og karismatisk sindede kirker (jf. Jensen 2020a). I store træk kan disse to parter opdeles i to lejre - den første i den lejr, som tror på, at menneskeheden er i en slags venteperiode imellem Jesu opstandelse og himmelfart og Jesu tilbagevenden. Den anden gruppe er af den tro, at siden Jesu død og opstandelse er den Hellige Ånd blevet tilgængelig for enhver troende, og at Gud virker i meget konkret forstand $\mathrm{i}$ det daglige. To passager fra Bibelen fungerer som eksempel på den senere gruppes holdning. Den første er fra Mattæusevangeliet kapitel 27, vers 51, som omhandler det øjeblik, hvor Jesus dør på korset: „Og se, forhænget i templet flængedes i to dele, fra øverst til nederst ...", mens den anden passage findes i Apostlenes Gerninger kapitel 2, vers 1-4: „Da pinsedagen kom, var de alle forsamlet. Og med ét kom der fra himlen en lyd som af et kraftigt vindstød, og den fyldte hele huset, hvor de sad. Og tunger, som af ild viste sig for dem, fordelte sig og satte sig på hver enkelt af dem. Da blev de alle fyldt af Helligånden, og de begyndte at tale på andre tungemål, alt efter hvad Ånden indgav dem at sige." Hvor den senere passage er velkendt som grundlaget for pinsebevægelsen generelt, omhandler den forrige noget af det samme. Den bevidner den trossætning, at ved Jesu død blev Det Allerhelligste ${ }^{5}$ frigivet til alle mennesker, hvorimod det i Det Gamle Testamente er forbeholdt præster og skriftlærde, eller når Gud af egen vilje vælger at vise sig for udvalgte mennesker i bestemte situationer.

Det centrale spørgsmål, som jeg ser det, er, i hvor høj grad de forskellige former for kristendom tror på Guds fortsatte indvirkning i verden. For eksempel ser Charles Taylor (2007) dette spørgsmål som et af de mest afgørende, ikke kun for hvordan den vestlige verden er blevet sekulariseret inden for de seneste 2-300 år, men også for de former, som kristendom har taget under samme tidsperiode (jf. dette særnummers introduktion). Taylor argumenterer for, at bevægelser såsom deisme blev eksemplariske for dette. I deisme ser vi en tro på Gud som den „fraværende skaber" - en Gud, som skabte verden, sådan som det er fremlagt i Bibelen, men som herefter har trukket sig ud af verden og lader historien udspille sig ud fra den oprindelige plan. Vi kan igen henvise til dispensationalismen her og forstå dette som to distinkte perioder - en. hvor Gud var til i Skabelsen, og en efter, hvor mennesket selv forsøger at opnå forbindelsen til det hellige. Men her kan pinse- og karismatiske kirker på ingen måde være enige med deisterne. Absolut centralt for disse kirker er nemlig den måde, hvorpå Gud igennem den Hellige Ånd stadig virker i menneskers liv. Hvor der ikke eksisterer nogen klar forbindelse mellem Brødrene på Færøerne og den deistiske bevægelse, er der dog ligheder, specielt i form af en calvinistisk tro på, at Ordet (forstået som den bibelske kanon) med tiden skulle komme til at erstatte nødvendigheden af Åndens direkte indvirkning i menneskers liv (Jensen 2020a; jf. Ruthven 1993). 
Under mit etnografiske feltarbejde blandt medlemmer i City Church har en gennemgående bestanddel været min egen tilstedeværelse i den kristne lokalradio, Lindin. Hver onsdag morgen gennem flere måneder har jeg været med, mens Andrias, City Churchs tidligere pastor, har en tre timers udsendelse, hvor han udlægger sit syn på Bibelens budskab. Som Andrias selv påstår, har hans udlægning af dette budskab altid været totalt anderledes end den almindelige kristne retorik på Færøerne. Han siger, at på Færøerne har der almindeligvis været en tendens til, at den eskatologiske retorik har haft en central plads, og at budskabet har fokuseret på verdens ende, individets personlige frelse og spørgsmålet om, hvor ens sjæl ender, når man dør - enten i Himmelen eller i Helvede. Andrias blev født og voksede op blandt Brødrene, og han siger uden at tøve, at det er denne gruppes stærke position i færøsk kristent liv, som har formet denne retorik. Efter at Andrias selv brød med denne gruppes lærdom, da han var teenager, har han bevæget sig stadigt længere og længere hen imod den lære, som findes hos pinsekirkerne og de karismatiske kirker.

Næsten hver uge handler Andrias' budskab disse onsdag morgener om det velsignede liv, den frihed, som findes i den personlige relation to Gud, som omtales i Det Nye Testamente. Hvad der er centralt i dette budskab, er, som vi allerede har set, at gennem Jesu død og genopståen er det velsignede liv igennem den Hellige Ånd blevet tilgængeligt for alle troende. Andrias siger, at dette er et budskab, som handler om liv. Men ikke kun liv, men som han plejer at sige, ,et liv i overflod“ (Eriksen et al. 2019). Det er denne overflod, som strømmer fra Guds væsen, som er, hvad jeg påpeger som Guds mirakuløse indgriben i verden (Marshall 2010; Bialecki 2017). Igennem denne indgriben kan mennesker blive skubbet $i$ uventede retninger, som tilsyneladende ikke er givet til almindelige kausale forestillinger (Marshall 2010:205). ${ }^{6}$ Den centrale idé i vores eget tilfælde er, at Gud står klar og vil for alt i verden udgyde af sin velsignelse. Men (og her begynder vi at ane den rolle, som bøn har for medlemmer af denne bevægelse) man skal bede om det, og den mest almindelige måde, hvorpå individet kan bede om dette velsignede liv, er ved aktivt at indgå i en relation med Gud. Bøn bliver således et gennemgående element i den (nye) troendes liv, i og med at han eller hun gør sig åben for at modtage Guds nærvær, både som kommunikation og som velsignelser i materiel eller anden form. Her kan vi dog ane et dilemma, som synes at være i modsætning til, hvordan Guds person ofte bliver begrebsliggjort. Blandt bevægelsens medlemmer er det en gennemgående læresætning, at Gud er almægtig, og at han har en handlingskraft, som er både langt større end og ikke kun forbundet med menneskers ønsker og bekymringer. Så hvorfor skal man bede om velsignelsen? Hvorfor velsigner Gud ikke bare ud fra sin egen dømmekraft om, hvornår denne velsignelse skal uddeles, og hvem han synes skal modtage den? 


\section{Den personlige Gud}

Men der kommer en time, ja, den er nu, da de sande tilbedere skal tilbede Faderen i ånd og sandhed. For det er sådanne tilbedere, Faderen vil have (Johannes 4:23).

Juleaften 2018 havde City Church organiseret en gudstjeneste klokken to om eftermiddagen. Her var samlet omkring 100 mennesker, og på programmet var forskellige indslag. Et af disse var oplæsning af en børnehistorie, og den blev læst op af Jógvan, som er en af de personer i kirken, som har brugt flere år i bibelskole. I Jógvans tilfælde var dette på en skole i Tromsø i Norge, hvor han og hans kone boede i flere år, da de var først i 20'erne. De er i dag begge midt i 40'erne, og under gudstjenesten udviser Jógvan sine formidable formidlingsevner, når han forklarer Guds relation til menneskeheden igennem en historie, hvor en bedstefar forklarer sit barnebarn, hvad julen handler om. Nemlig at Gud ofrede sin søn Jesus for at kunne skabe en relation til mennesker, som bliver gjort mulig gennem Jesu død på korset og genopståen. Når historien er slut, og Jógvan begynder at udlægge noget af sin egen fortolkning af budskabet, tager han et af de mere centrale spørgsmål op: Hvorfor skabte Gud menneskeheden til at starte med? Hvorfor er denne historie om skabelse, fald og den gendannede relation mellem Gud og mennesker igennem Jesus så vigtig for Gud? Med andre ord - hvor det er mere velkendt, at mennesket behøver frelse for egen skyld, hvorfor er relationen så vigtig for den anden side af lignelsen - hvad får Gud af det? Jógvan slår med ét fast: Gud skabte menneskeheden, fordi Han havde brug for relationen. Som afsnittets epigraf bevidner, er der her en tro på, at menneskeheden blev skabt, for at Gud selv kunne have en relation med mennesker, en relation, som er baseret på tilbedelse og menneskets anerkendelse af, at det sande, gode liv kun findes i Guds nærvær.

Det er for mig slående i den antropologiske litteratur, at selv om ideen om „den personlige Gud" "er meget central inden for studier af kristendom (se fx Harding 2000; Luhrmann 2012), er der ofte en mangel på forståelse af, hvad dette indebærer. Specielt når vi inddrager begrebet „relation“, forekommer det mig, at „,den personlige relation til Gud" ofte handler om, hvad individet kan få ud af denne relation - det kan være velsignelser (Coleman 2000), personlig helbredelse eller vækst (Csordas 1994; Meyer 1998) eller sjælens frelse (Robbins 2004). Hvad der kan mangle i denne forståelse af, hvad en personlig relation til Gud indebærer, er, hvad der flyder den anden vej, altså, hvad mennesket kan tilbyde Gud, som gør, at denne relation er ønskværdig for begge parter. Med andre ord - hvad får Gud ud af denne relation? Her læner jeg mig op ad nogle af de diskussioner, som har været af forholdet mellem antropologi og teologi. Disse diskussioner kan siges at ligge tæt på de senere års generelle antropologiske interesse for forskellige 
ontologier. Centralt for disse diskussioner, som jeg ser det, er spørgsmålet om, hvilke verdener folk bebor, og kan i bred forstand ses som et forsøg på at decentralisere antropos fra sociale teorier for at give mere plads til ikke-menneskelige aktører (jf. Holbraad \& Pedersen 2017). Ud fra samme generelle tankesæt opstår selvfølgelig spørgsmålet om, hvor vi skal finde Gud i analyser af kristne grupper. Til dette formål har flere antropologer vendt sig til teologi for at skabe en bedre forståelse af forholdet mellem menneskeheden og Gud (Bialecki 2014b, 2018; Lemons 2018; Robbins 2020). ${ }^{7}$ Det er her, at jeg mener, at tilbedelse kan være en vigtig optik for forståelsen af, hvad der er på spil i forholdet mellem menneskeheden og den kristne Gud.

Gennem min tid sammen med medlemmer af City Church er der et element af kirkeliv, som bliver fremhævet blandt folk, jeg snakker med, nemlig den del af gudstjenester, hvor musik og fællessang står centralt. Til en almindelig søndagsgudstjeneste fylder denne del omkring halvdelen af den totale længde med talen som den anden hoveddel. I omkring 45 minutter fra starten af gudstjenesten klokken 11 hver søndag ${ }^{8}$ fylder tilbedelse kirken, og medlemmer af kirken, som generelt udviser en meget rolig og stille natur, bliver mere kropsligt animerede. Salen bliver fyldt med sang og dans, mens nogle lukker øjnene i stille bøn, og andre beder i tunger med armene hævet mod loftet. Orkestret består som oftest af omkring otte personer, og sangene bliver sunget på både færøsk og engelsk. ${ }^{9}$ Sangene varierer alt fra stille tilbedelsessange til „upbeat" rocknumre, og sammensætningen af disse sange, og hvordan de skal flyde sammen (som de ofte gør - ofte kører orkestret direkte fra det ene nummer til det andet uden stop), bliver bestemt af orkestret forinden. Ud af alle kirkens aktiviteter er der ingen andre, som får lige så meget opmærksomhed og indsats som musikken, om det så er musikere, sangere, teknikere eller andet mediepersonale, som står for dem.

Det er i disse øjeblikke, at folk oftest omtaler, at de føler Guds nærvær. Dog varierer denne oplevelse meget blandt kirkens medlemmer - til tider som noget, som sker inde i en selv, og til tider som en materiel manifestation af Guds nærvær uden for en selv. Men her er det vigtigt at påpege, at grænserne mellem, hvad der er inden for, og hvad der er uden for individet, kan være svære at skelne. Johanna, en 23-årig ung kvinde, fortæller engang, hvordan hun efter en lang periode med personlige vanskeligheder endte med at tage på en bibelskole for unge kvinder i England. Denne bibelskole specialiserer i at hjælpe unge kvinder med at finde tilbage til et normalt liv efter personlige problemer. Disse problemer kan være alt fra alkohol- og narkotikamisbrug, cutting og andre former for selvskade til oplevelse af vold af forskellig natur. I Johannas tilfælde startede hendes vanskeligheder med, at hun som barn blev fjernet fra sine forældre på grund af deres vedvarende alkoholmisbrug, og hun blev placeret hos en plejefamilie. Da Johanna 
blev teenager, begyndte hun at gå i byen til langt ud på natten. Da det stod værst til, fortæller hun, var hun i byen på værtshuse og diskoteker fire eller fem dage om ugen, mens hun både gik i skole og arbejdede ved siden af. En dag blev det for meget for Johanna, og igennem sin søster endte hun med at tage til et møde i City Church, og efter få måneder blev hun opfordret til at at tage på bibelskolen i England af nogle af kirkens ledere. Johanna fortæller, at hendes stærkeste og mest klare oplevelse af, at Guds nærvær kom til hende, var under en tilbedelsesaften i bibelskolen. Mens hun stod der sammen med sine venner dybt engageret i tilbedelse i form af sang, bøn og tungetale, hørte hun ordene eg elski teg komme fra den unge kvinde, som stod lige ved siden af hende. Det er færøsk for ,jeg elsker dig“, og Johanna var overbevist om, at det var Gud, som talte til hende igennem hendes venindes tungetale. ${ }^{10}$

Det skal understreges, at i dette eksempel sker Guds indtræden gennem en tredje aktør. Hvor jeg lige har sat forholdet mellem Gud og individ i tilbedelse og bøn som værende enten en oplevelse af nærvær, som kommer indefra, eller Guds nærvær, som lægger sig på individet uden sidstnævntes eksplicitte kontrol eller vilje, er dette i sidste ende en bevægelse enten indefra eller udefra. ${ }^{11} \mathrm{Hvad}$ Johannas historie viser os, er, at Guds nærvær ikke kun sker i disse retninger, men snarere at Guds nærvær bliver til i en cirkulation mellem Gud, individ og den større sociale sammenhæng (Webster 2017). Mit argument er her, at dette problematiserer den ofte citerede sætning inden for de former for kristendom, som jeg omtaler her, nemlig at den personlige relation til Gud kun eksisterer mellem individ og Gud (jf. Bialecki \& Daswani 2015; Daswani 2011; Mosko 2010; Robbins 2002). Hellere skal vi huske, at for disse kristne bevægelser er der den tidligere nævnte centrale tro på, at Gud eksisterer og handler overalt til alle tider, og at Gud ikke kun handler i den troendes liv, efter at en person har valgt at indgå i den guddommelige relation. Hvis vi vender tilbage til mit tidligere eksempel fra radioen, kan vi sige, at Gud allerede er i gang med at udsende alt sit nærvær, men at det først er, når individet lærer at „høre rigtigt“", at han eller hun kan komme til at genkende denne kommunikation som værende fra Gud. Ved at indgå i det personlige forhold med Gud, oftest i forskellig form for bøn eller tilbedelse, bliver individet således indstillet på at modtage Hans nærvær og velsignelse.

\section{Indstilling og selvets teknologier}

Spørgsmålet om, hvordan individer kommer til at høre Gud eller på andre måder kommer til at opleve sidstnævntes nærvær i deres liv, har i senere år været centralt for mange studier af religion inden for antropologi. Stærkt påvirket af de senere værker af Michel Foucault har dette arbejde sat fokus på de måder og de 
forskellige teknologier ( $\mathrm{i}$ bred forstand), som individer arbejder med sig selv på i et forsøg på at komme til at blive de etiske subjekter, som i den givne kontekst ses som værende ønskværdige. Disse studier findes i mange forskellige kontekster, hvor nogle af de mest kendte er inden for karismatiske kristne kredse (Luhrmann 2012; Robbins 2004) og hos fromme muslimer (Hirschkind 2001; Mahmood 2005). Hvad disse studier har lagt vægt på, er, at religiøse subjekter ikke kun er underlagt strenge regler og normer, som de gør deres bedste for at leve op til, men at disse subjekter selv er med til at skabe ikke kun sig selv som subjekt, men også er med til at varetage og producere de etiske verdener, som de er en del af. Men i tråd med mit argument i denne artikel kunne dette siges at være lidt for antropocentrisk. Amira Mittermaier (2012) har også argumenteret for, at hvor den analytiske trope om det religiøse subjekt, som arbejder med sig selv og sin omkringliggende etiske verden, har haft meget godt at sige gennem de senere år, har denne tænkning en indbygget risiko for at flytte det religiøse subjekt fra den ene fastlåste position (hvor han eller hun kun følger forudbestemte regler) til en helt anden, hvor al religiøs oplevelse i sidste ende kun er et produkt af det etiske arbejde med selvet. Tag som eksempel Tanya Luhrmanns velkendte værk When God Talks Back (2012). I denne bog bruger Luhrmann psykologisk inspirerede analyser for at vise, hvordan oplevelsen af at høre Gud kommer af en bestemt måde at indstille sig på at opleve sit eget sanseliv. Igennem forskellige former for teknologier ${ }^{12}$ såsom bøn og intensiv bibellæsning indstiller individet sig på at opleve sanseindtryk og daglige oplevelser som værende tegn på Guds nærvær.

Som Mittermaier også påpeger, udelader denne analyse en central faktor i den personlige relation mellem subjekt og Gud, den fratager Gud nemlig al handlekraft. Som jeg har vist igennem denne artikel, strider dette stærkt imod, hvordan kristne på Færøerne oplever deres relation til Gud. Selv om vi kan acceptere, at det som oftest kræver en vis personlig indsats for at komme til det punkt, hvor individet kan komme til at opleve Gud på den meget konkrete måde, som jeg har vist, udelukker dette ikke, at når denne minimumstilstand af åbenhed er opnået, kan oplevelsen føre individet ned ad veje, som han eller hun ikke selv har kontrol over. ${ }^{13}$ Denne åbenhed for at blive handlet på er, hvad jeg kalder den karismatiske subjunctive indstilling. Subjunctive er en grammatisk form, som indeholder et rum for potentialitet og usikkerhed. Et eksempel kunne være „Længe leve kongen", som i sig selv ikke siger, at kongen kommer til at leve i mange år, men snarere udtrykker et ønske om, at dette må ske. Det skal understreges, at denne forståelse af det subjunctive er meget lig den tidsforståelse, som Andreas Bandak og Simon Coleman kalder det proleptiske (Bandak \& Coleman 2019), nemlig at tidsforståelsen i den givne situation ikke kun er baseret i fortid og nutid, men også at fremtiden har en eksistens i nutiden med al den potentialitet, som 
dette indebærer (jf. Boellstorff 2011:290). I vores tilfælde kan vi sige, at hvor bønnen delvist er en praksis, som udleves i nutiden, er en af de underliggende logikker nemlig en ,investering“ " $\mathrm{i}$ fremtiden, forstået som en subjunctiv udlevelse af, hvad personen må forvente kommer til at ske.

Når det kommer til den karismatiske form for bøn, har vi allerede set, at ligesom en radio skal indstilles rigtigt for at kunne modtage en bestemt kanal, er det en nødvendighed for individet at være indstillet rigtigt for at kunne modtage Guds personlige budskab og indivirken i sit liv. Det kræver først og fremmest, at individet åbner sig for den subjunctive mulighed for, at han eller hun kan blive påvirket af en udefrakommende agens, som kan føre hans eller hendes liv i uforudsete retninger. Dette åbner for spørgsmålet om forholdet mellem individers bøn og den guddommelige cirkulation af nærvær og velsignelse eller med andre ord, hvordan bønnen selv bliver del af cirkulationen. Det er mit argument her, at bøn skal ses som et bidrag til denne gennemgående cirkulation, hvor Gud står klar til at velsigne alle de personer, som begiver sig ud i at være en del af cirkulationen. Denne cirkulation er meget lig den, som vi ser i Jean og John Comaroffs idé om „okkulte økonomier“. Disse økonomier har to dimensioner: et materielt aspekt, som synes at producere overskud uden om konventionelle, rationelle forklaringer, og et etisk aspekt, som er baseret på de moralske diskurser og handlinger, som følger af denne overskudsproduktion (Comaroff \& Comaroff 2000:19). Ud fra denne idé om den rigdom (materiel eller andet), som findes i evigt omløb, er bøn og tilbedelse således individets bidrag, som holder økonomien kørende. Som vi så tidligere, skal dette ses i stærk sammenhæng med troen på, at det mirakuløse er i stand til at skabe velsignelser (eller for at holde os til det økonomisk betonede sprog - værdier), og det er her, at den troende ved at indstille sig på den evige cirkulation kan gøre sig håb om, at disse velsignelser skal komme ham eller hende til gode.

For at brede ideen om cirkulationen af Guds nærvær endnu længere ud, kan vi påpege, at det fællesskab, som der er tale om, ikke kun omfatter de karismatiske kirker på Færøerne. Vi har allerede set i Johannas tilfælde (og til dels af Jógvans teologiske studier i Norge), hvordan medlemmer af de færøske kirker er mobile og har forbindelser til mange kirker og individer rundtomkring $\mathrm{i}$ verden. Som Firouz Gaini (2013) har påvist, er ideen om det isolerede øsamfund midt i Atlanterhavet uden substantiel påvirkning udefra ikke særlig brugbar, når det kommer til analyser af Færøerne. Også inden for kristne trossamfund har der i lang tid været en støt strøm af kristne budskaber og medier ind i landet. ${ }^{14}$ I senere år er denne strøm blevet stadigt mere digital, og sociale medier såsom Facebook og Instagram er i dag en helt naturlig del af det kristne liv. Et af de mest nævneværdige elementer af denne strøm er udenlandske prædikener 
og andre former for kristne medier. I den periode, hvor jeg har lavet feltarbejde i kirken, er der en person, som er delt mere end nogen andre på de sociale medier. Steven Furtick startede i 2006 sammen med syv andre familier Elevation Church i Matthews, North Carolina. Elevation Church er siden vokset markant og omfatter nu 17 kirker i Nordamerika. Denne kirke lægger vægt på et stærkt kristent budskab, som bliver sendt over hele verden over nettet, både live og med redigerede videoer af prædikener og musikvideoer. Ligesom Elevation Church har City Church senere år lagt stadig mere vægt på sin tilstedeværelse på internettet, og til dels kan inspirationen til dette føres tilbage til det eksempel, som Elevation Church og lignende kirker er. ${ }^{15}$

Furticks prædikener kan siges at være stærkt inspirerede af inspirationslitteratur på grænsen til selvhjælpslitteratur med meget vægt på den styrke, som kan findes $i$ at leve et liv sammen med Gud. Gennem flere måneder så jeg fx en af Elevation Churchs musikvideoer flere gange sammen med mine informanter. Titlen på denne video er „I Will Be Confident. Motivational Track from Pastor Steven Furtick", og det er en 3 minutter og 12 sekunder video med billeder af unge atleter og musikudøvere, som synes at kæmpe med deres arbejde. Nummeret er et „spoken word“-musiknummer med tunge trommer og bas, hvor Furtick selv taler (og til tider skriger) nummerets tekster, som i store træk handler om den selvtillid, som er til at få, om man lader Gud være sin styrke i livet. Men udover de fangende musiknumre og -videoer er både Furticks personlige YouTube-side og Elevation Churchs YouTube-side fyldt med videoer af Furticks prædikener. En af disse prædikener blev delt af et af City Churchs medlemmer, og prædikenen har titlen „Need Encouragement?“. Denne prædiken blev først lagt ud på YouTube den 3. marts 2020, og selv om den i store træk handler om, hvordan individer kan finde opmuntring til at klare sig igennem svære tider, indeholder prædikenen en sekvens, som opsummerer, hvordan det karismatiske subjekt, sådan som vi har forstået det indtil videre, står i forhold til den cirkulation af Guds nærvær og velsignelse, som vi har set.

Denne sekvens tager fat i den ofte anvendte funktion, som olie har i Bibelen. Igennem forskellige bøger i både Det Gamle og Det Nye Testamente finder vi olie (nogle gange også kaldt salve) som en af de mest hellige materielle substanser, der bliver anvendt i kristent ritual (se fx 2. Mosebog, kapitel 30). Hvor olien i Det Gamle Testamente har en meget klar rituel funktion, fungerer olien i Det Nye Testamente ofte i mere metaforisk form og kan siges at betyde en mere eller mindre hellig substans, som er begrænset i mængde, og som skal forvaltes med megen omhu. Furtick tager fat i denne metaforiske betydning af olien, og i sin prædiken kommer han ind på det problem, som mange kristne (og mennesker generelt) oplever, nemlig at man kan opleve, at den indsats og de personlige 
ofre, man giver for andre og Gud, ofte kan synes ikke at give noget resultat, og at personen ofte oplever, at han eller hun sidder tilbage i nederlag, hvor ens „olie“ er blevet spildt. Furtick siger, at denne oplevelse af skuffelse og tab ikke er ualmindelig, og at den ofte kan synes at være en naturlig del af livet som kristen. Men, siger han, den eneste måde at bevæge sig fremad i sine relationer med andre mennesker og Gud på er ved at blive ved med at forsøge at give af sin „olie“ og at blive ved med at leve et opofrende liv, som er basis for, at Gud kan bruge mennesker til at dele ud af sin velsignelse. Det er her, at jeg vil påpege, at for mig synes der at være stærk resonans mellem, hvordan bøn og offer forstås blandt medlemmerne af den kristne bevægelse på Færøerne, som jeg har omtalt i denne artikel (Hubert \& Mauss 1964; Mayblin \& Course 2014; Robbins 2017). ${ }^{16}$ Som vi har set, er bøn ikke kun en kommunikationsform mellem personer og Gud, men bøn har en vis „vægt“ (jf. Voloshinov 1986; Harkness 2010) i den cirkulation af velsignelse og offer, som disse kristne er en del af. Det er mit argument her, at ved at inddrage bøn som en del af en bredere kontekst af guddommelig cirkulation, kan vi tilnærme os en bedre forståelse af, hvordan bøn får liv og færdes imellem både mennesker og Gud (jf. Coleman 2004, 2011).

\section{Konklusion}

I denne artikel har jeg vist, at inden for såkaldte karismatisk betonede kirker figurerer bøn meget både i sociale sammenhænge og i medlemmers individuelle religiøse liv. Bøn kommer i disse sammenhænge til udtryk i forskellige former, men den gennemgående betydning af bønnen ligger i dens direkte forbindelse mellem mennesker og Gud. Bøn skal ikke kun ses som en afgrænset praksis med en begyndelse og ende, men hellere som en form for relation, eller i det mindste skal bøn ses som den måde, hvorpå en bestemt relation udspiller sig. Endvidere kan vi dermed også forbinde bøn med en anden form for kristent åndsliv, nemlig tilbedelse. I denne artikel har jeg vist, hvordan denne slags relationsbaseret bønsliv kommer til udtryk blandt medlemmer af City Church i Tórshavn, Færøerne. Denne kirke tror på, at det bedste kristne er et liv, hvor Gud har en finger med i spillet $i$ alle livets omstændigheder, og derfor er bøn, tilbedelse og andre former for åndeligt nærvær et konstant element blandt medlemmer af kirken. Jeg har argumenteret for, at denne måde at forholde sig til Gud og verden på bedst forstås som en subjunctive indstilling, som har til formål at gøre den troende åben for, at Gud kan virke mirakuløst i deres liv. Denne mirakuløse deltagelse i menneskers liv bliver endvidere forstået som værende del af en cirkulation, som bøn og personlige ofre er med til at holde kørende. 


\section{Noter}

1. Jeg har valgt at bruge det engelske udtryk i stedet for det mere kringlede „konjunktiv“, som det hedder på dansk. Det skyldes, at jeg mener, at den danske oversættelse ikke helt indfanger meningen, som begrebet har på engelsk.

2. https://hagstova.fo/fo/foC3\%B3lk/f\%C3\%B3lkatal/f\%C3\%B3lkatal.

3. Sammenlignet med omkring 2,4 procent af den danske befolkning, som ugentligt går i kirke (Hansen 2014:14).

4. Courtney Handman har argumenteret for, at der inden for antropologiske analyser har været en mangel på opmærksomhed på, hvordan kristne kirker og menigheder forholder sig (ofte kritisk) over for hinanden (Handman 2015; jf. Bialecki 2014b).

5. Blandt mine informanter bliver dette oftest omtalt som Guds personlige nærvær.

6. Den samme logik kunne eksempelvis overføres på økonomiske systemer, hvor et begrænset omfang af værdier er i cirkulation (Graeber 2011). Denne diskussion er del af den noget længerevarende interesse for forholdet mellem kontinuitet og radikale brud (Meyer 1998; Robbins 2007) samt kristne gruppers tanker om deres egen historisk-teologiske position i verden (Agamben 2010; Bialecki 2009; Harding 2000; Webster 2013).

7. Vi kan kalde antropologi studiet af antropos’ væsen og sammenstille dette med teologi som studiet af teos væsen. Inden for den kristne kosmologi er denne opdeling dog højst problematisk, i og med at „Gud skabte mennesket i sit billede“ (1. Mosebog 1:27), som dermed lægger op til en vis grad af kontinuitet imellem de to.

8. Starttidspunktet flyder dog næsten altid med op til 15 minutter, og starten bliver uformelt besluttet af orkestret, som starter, når de synes, det er passende (jf. Bialecki 2017; Shoaps 2002).

9. De allerfleste sange, som bliver spillet, er af international karakter, og der er en reel industri omkring dette med bevægelser som Hillsong (Australien) og Bethel (USA), som de mest indflydelsesrige (dog er den globale cirkulation af elementer af tilbedelse ikke nogen ny udvikling, jf. Martin 2002). På Færøerne har det i mange år været almindeligt at oversætte disse sange til færøsk til brug i gudstjenester.

10. Tungetale findes hovedsageligt $i$ to forskellige former. Den første er glossolalia forstået som en direkte forbindelse mellem Gud og individ, og hvor selve sproget er Guds eget sprog. Den anden form for tungetale er xenoglossia, som betyder, at individet, som beder, făr adgang til og evne til at tale sprog, som han eller hun aldrig har lært (Harkness 2021). I eksemplet ovenfor er det således sidstnævnte form, som er i spil.

11. For en mere dybdegående udlægning af, hvordan ritual ofte handler om at sætte bestemte bevægelser i gang, se Tomlinson (2014).

12. Begrebet teknologi her skal forstås i bred forstand, som det findes hos Foucault $(1985,1997)$. Teknologier kan være alt, som subjektet gør brug af for at opnå det ønskede (etiske) resultat. Her kan bøn være en teknologi, ligesom selvpiskning kan være det. Det centrale er, at disse teknologier har til formål at flytte subjektet fra en tilstand til en anden.

13. Josh Brahinsky (2018) har argumenteret for, at kontrolleret arbejde med selvet og den spontane oplevelse af udefrakommende spirituelt nærvær ikke nødvendigvis udelukker hinanden.

14. Strømmen går også den anden vej, og de fleste kristne kirker er involveret i diverse missionsog hjælpeorganisationer.

15. I løbet af 2020 er dette aspekt blevet en stadig mere vigtig del af City Churchs profil udadtil set i lyset af COVID 19-pandemien, og hvordan denne har forårsaget, at mange gudstjenester 
og andre tiltag er blevet aflyst. Af samme grund har City Church gjort en stor indsats for at udvikle sit udtryk online (Jensen 2020b).

16. Dette er endnu mere substantieret af, at den monetære donation, som er en del af hver søndagsgudstjeneste, bliver kaldt offer, og endvidere- at dette bliver omtalt som en form for tilbedelse. Dette bliver ofte kaldt for at ,give ind i Guds rige“.

\section{Litteratur}

Agamben, Giorgio

2010 The Time that Remains. A Commentary on the Letter to the Romans.

Stanford: Stanford University.

Bandak, Andreas \& Simon Coleman

2019 Different Repetitions. Anthropological Engagements with Figures of Return,

Recurrence and Redundancy. History and Anthropology 30:119-32.

https://doi.org/10.1080/02757206.2018.1547900.

Bialecki, Jon

2009 Disjuncture, Continental Philosophy's New "Political Paul," and the Question of Progressive Christianity in a Southern California Third Wave Church. American Ethnologist 36:110-23.

2014a After the Denominozoic. Evolution, Differentiation, Denominationalism. Current Anthropology 55:193-204.

2014b Does God Exist in Methodological Atheism? On Tanya Luhrmann's When God Talks Back and Bruno Latour. Anthropology of Consciousness 25:32-52. https://doi.org/10.1111/anoc.12017.

2017 A Diagram for Fire. Miracles and Variation in an American Charismatic Movement. Oakland: University of California Press.

2018 Anthropology, Theology, and the Problem of Incommensurability. In: J.D. Lemons (ed.): Theologically Engaged Anthropology. Oxford: Oxford University Press.

Bialecki, Jon \& Girish Daswani

2015 What is an Individual? The View from Christianity. HAU: Journal of Ethnographic Theory 5:271-94. https://doi.org/10.14318/hau5.1.013.

Boellstorff, Tom

2011 But Do not Identify as Gay. A Proleptic Genealogy of the MSM Category. Cultural Anthropology 26:287-312. https://doi.org/10.1111/j.1548-1360.2011.01100.x.

Brahinsky, Josh

2018 The Effects of Scale. How Western Agency-Anxieties Mold Affect Theory, and how Pentecostalism and Neuroscience Teach Us to Think Differently. Anthropological Theory 18:478-501.

Coleman, Simon

2000 The Globalisation of Charismatic Christianity. Spreading the Gospel of Prosperity. Cambridge: Cambridge University Press.

2004 The Charismatic Gift. The Journal of the Royal Anthropological Institute 10:42142. https://doi.org/10.1111/j.1467-9655.2004.00196.x.

2011 Prosperity Unbound? Debating the "Sacrificial Economy". Research in Economic Anthropology 31:23-45. 
Comaroff, Jean \& John Comaroff

2000 Millennial Capitalism. First Thoughts on a Second Coming. Public Culture 12: 291-343. https://doi.org/10.1215/08992363-12-2-291.

Csordas, Thomas J.

1994 The Sacred Self. A Cultural Phenomenology of Charismatic Healing. London: University of California Press.

Daswani, Girish

2011 (In-)Dividual Pentecostals in Ghana. Journal of Religion in Africa 41:256-79. https://doi-org.ep.fjernadgang.kb.dk/10.1163/157006611X586211.

Eriksen, Annelin, Ruy Llera Blanes \& Michelle MacCarthy

2019 Going to Pentecost. An Experimental Approach to Studies in Pentecostalism. New York \& Oxford: Berghahn Books.

Foucault, Michel

1985 The History of Sexuality. Vol 2: The Use of Pleasure. New York: Penguin Books.

1997 Ethics, Subjectivity and Truth. Essential Works of Foucault 1954-1984. New York: The New Press.

Gaini, Firouz

2013 Lessons of Islands. Place and Identity in the Faroe Islands. Tórshavn: Fróðskapur.

Graeber, David

2011 Debt. The First 5,000 Years. Brooklyn, NY: Melville House.

Handman, Courtney

2015 Critical Christianity. Translation and Denominational Conflict in Papua New

Guinea. Berkeley: University of California Press.

Hansen, Gerhard

1984 Vækkelsesbevægelsernes møde med færingernes enhedskultur. En analyse ca.

1850-1918. Tórshavn: Føroya Fróðskaparfelag.

Hansen, Janna

2014 Betwixt and Between. Religion og religiøsitet på Færøerne i det 21. århundrede. Tórshavn: Fróðskapur.

Harding, Susan F.

2000 The Book of Jerry Falwell. Fundamentalist Language and Politics.

Princeton: Princeton University Press.

Harkness, Nicholas

$2010 \quad$ Words in Motion and the Semiotics of the Unseen in Two Korean Churches. Language \& Communication 30:139-58. https://doi.org/10.1016/ j.langcom.2009.05.002.

2021 Glossolalia and the Problem of Language. Chicago \& London: University of Chicago Press.

Haynes, Naomi

2020 The Expansive Present. A New Model of Christian Time. Current Anthropology 61:57-76. https://www.doi.org/10.1086/706902.

Hirschkind, Charles

2001 The Ethics of Listening. Cassette-Sermon Audition in Contemporary Egypt. American Ethnologist 28:623-49. https://doi.org/10.1525/ae.2001.28.3.623. 
Holbraad, Martin \& Morten Axel Pedersen

2017 The Ontological Turn. An Anthropological Exposition. Cambridge: Cambridge University Press.

Hubert, Henri \& Marcel Mauss

1964 Sacrifice. Its Nature and Function. Chicago: Chicago University Press.

Jensen, Jan

2020a Christianity, Presence, and the Problem of History. Suomen Antropologi: Journal of the Finnish Anthropological Society 45:3-16. https://doi.org/10.30676/ jfas.v45i2.90016.

2020b COVID-19. Christians in the Faroe Islands. Religion and Global Society. London School of Economics. https://blogs.lse.ac.uk/religionglobalsociety/category/covid19/. Læst 18.8.2020.

Jóansson, Tórður

2012 Brethren in the Faroes. An Evangelical Movement, its Remarkable Growth and Lasting Impact in a Remote Island Community. Tórshavn: Fróðskapur.

Lemons, J. Derrick (ed.)

2018 Theologically Engaged Anthropology. Oxford: Oxford University Press.

Luhrmann, Tanya M.

2012 When God Talks Back. Understanding the American Evangelical Relationship with God. New York: Vintage Books.

Mahmood, Saba

2005 Politics of Piety. The Islamic Revival and the Feminist Subject. Princeton:

Princeton University Press.

Marshall, Ruth

2010 The Sovereignty of Miracles. Pentecostal Political Theology in Nigeria.

Constellations 17:197-223. https://doi.org/10.1111/j.1467-8675.2010.00585.x.

Martin, David

2002 Pentecostalism. The World their Parish. Oxford: Blackwell.

Mayblin, Maya \& Magnus Course

2014 The Other Side of Sacrifice. Introduction. Ethnos 79:307-19. https://doi.org/ $10.1080 / 00141844.2013 .841720$.

Meyer, Birgit

1998 "Make a Complete Break with the Past". Memory and Post-Colonial Modernity in Ghanaian Pentecostal Discourse. In: R. Werbner (ed.): Memory and the Postcolony. African Anthropology and the Power of Critique. London: Zed Books.

Mittermaier, Amira

2012 Dreams from Elsewhere. Muslim Subjectivities beyond the Trope of SelfCultivation. The Journal of the Royal Anthropological Institute 18:247-65. https://doi.org/10.1111/j.1467-9655.2012.01742.x.

Mosko, Mark

2010 Partible Penitents. Dividual Personhood and Christian Practice in Melanesia and the West. Journal of the Royal Anthropological Institute 16:215-40.

https://doi.org/10.1111/j.1467-9655.2010.01618.x. 
Robbins, Joel

2001 Secrecy and the Sense of an Ending. Narrative, Time and Everyday Millenarianism in Papua New Guinea and in Christian Fundamentalism. Comparative Studies in Society and History 43:525-51. https://doi.org/10.1017/S0010417501004212.

2002 My Wife Can't Break Off Part of Her Belief and Give It to Me. Apocalyptic Interrogations of Christian Individualism among the Urapmin of Papua New Guinea. Paideuma 48:189-206.

2004 Becoming Sinners. Christianity and Moral Torment in a Papua New Guinea Society. California: University of California Press.

2007 Continuity Thinking and the Problem of Christian Culture. Current Anthropology 48:5-38.

2017 Keeping God's Distance. Sacrifice, Possession, and the Problem of Religious Mediation. American Ethnologist 44:464-75. https://doi.org/10.1111/amet.12522.

2020 Theology and the Anthropology of Christian Life. Oxford: Oxford University Press.

Ruthven, Jon Mark

1993 On the Cessation of the Charismata. The Protestant Polemic on Post-Biblical Miracles. Tulsa: Word \& Spirit Press.

Shoaps, Robin A.

2002 "Pray Earnestly". The Textual Construction of Personal Involvement in

Pentecostal Prayer and Song. Journal of Linguistic Anthropology 12:34-71.

Taylor, Charles

2007 A Secular Age. Cambridge, MA, \& London: The Belknap Press of Harvard University Press.

Tomlinson, Matt

2014 Ritual Textuality. Pattern and Motion in Performance. Oxford: Oxford University Press.

Voloshinov, Valentin Nikolaevich

1986 Marxism and the Philosophy of Language. Cambridge, MA: Harvard University Press.

Webster, Joseph

2013 The Anthropology of Protestantism. Faith and Crisis among Scottish Fishermen. (Contemporary Anthropology of Religion). New York: Palgrave Macmillan.

2017 Praying for Salvation. A Map of Relatedness. Religion 47:19-34. https://doi.org/ 10.1080/0048721X.2016.1225905. 